\title{
The Sudanese Women's Movement and the Mobilisation for the 2008 Legislative Quota and its Aftermath
}

\author{
Sara Abbas:
}

Abstract This article explores the pathways of political action pursued by the Sudanese women's movement leading up to the introduction of a women's quota in 2008 and its implementation in the most recent 2010 national parliamentary elections, the country's first in 24 years. The article argues that the main achievement of the quota was the extent to which it mobilised women to engage in politics, rather than the increased representation of women in parliament. The form the quota took however, has not significantly challenged political parties to put forth women candidates in core geographic constituencies, restricting them instead to separate women's lists. The need for revisiting the quota, healing divisions within the women's movement and negotiating a robust common programme in the next phase are all critical for translating numbers into positive changes in Sudanese women's lives.

\begin{abstract}
1 Introduction
Legislative quotas, including for women, have been in operation in Sudan in one form or another for decades. However, women's access to parliament remained weak throughout the country's post-independence period and they have struggled to find ways to break through the historical patterns of male dominance that have largely excluded them from parliament, and which has kept them on the receiving end of laws and policies that have frequently marginalised and excluded them.
\end{abstract}

With the signing in 2005 of the Comprehensive Peace Agreement (CPA) between the ruling National Congress Party (NCP) and the Sudan People's Liberation Movement (SPLM), the country entered a new phase in its history. The agreement not only ended Africa's longest running civil war, and one of its bloodiest, but also set the ground for a return to multi-party elections which had eluded the country for nearly two decades. This article examines the period immediately leading up to and following the signature of the agreement from the perspective of the Sudanese women's movement in northern Sudan, which saw the agreement as representing a political moment apt for intensive mobilisation for a quota. The women's movement's efforts contributed to the enactment in 2008 of a 25 per cent quota for women in National Assembly (parliament) and Legislative Councils. ${ }^{1}$

Although quotas per se are not a new phenomenon in Sudan, the 2008 quota represents an important break with the past. Traditionally, women were either appointed to parliament under military regimes or won (very few) seats in periods of multi-party democracy through specially designated 'graduate constituencies'. These were seats reserved for urban professional groups unlikely to enter parliament given the dominance in the ballot box of the traditional sectarian parties, such as the Umma Party and the Democratic Unionist Party (DUP), the political wings of the Ansar and Khatmiyya sects whose bases were overwhelmingly rural and conservative (ElBattahani 2002). The 2008 quota is unique in that it not only targets women's representation specifically, but also seeks to guarantee it under conditions of multi-party democracy. Through examining the ways in which the women's movement in northern Sudan mobilised for the quota and divisions within the movement itself that ultimately impacted the form the quota 
took, this article seeks to draw some lessons from the experience and to offer some preliminary thoughts on the quota's implementation in the 2010 elections.

\section{Lessons of the Sudanese Political Women's Movement: 1965-2005}

The women's movement in Sudan has a rich political history that predates the country's independence in 1956. The first primary school for girls opened its doors in 1906 in Rufaa town under the leadership of Sheikh Babiker Badri, and in the ensuing years, a women's movement would be borne out of the national struggle against colonialism (Abdel-Al 1997). Formal women's organisations began to emerge starting in 1946, as the national struggle, led by trade unions, intensified against colonial authorities. Nurses were the first to break through cultural and colonial restrictions on women's participation in public life, taking part, in 1948 for the first time, in street demonstrations. The decisive moment in the history of the movement came with the formation of the Sudanese Women's Union (SWU) in 1952. In the beginning, the SWU did not have increasing women's political participation as a goal, its focus rested on health, education and labour issues (such as reducing female illiteracy, alleviating harmful practices affecting girls, ending discrimination in pay and increasing access to the labour market). With the 1953 elections looming, which were seen as a precursor to independence, SWU quickly entered the political sphere, agitating for women's right to vote, and making a breakthrough almost immediately when educated women (with a minimum of a secondary school certificate) were allowed to vote in graduate constituencies. In total, 15 women voted in that year's elections (Abdel-Al 1997).

SWU continued to build momentum, and by 1965, was regarded as a successful women-led grassroots organisation and a pioneer in the region. SWU was 15,000 members strong with local branches in various parts of the country. It held public demonstrations that challenged women's relegation to the home, and secured critical gains for Sudanese women, including the right to equal pay, maternity leave, and universal suffrage (1965). Respect for the SWU as a force within Sudanese political life had grown for the role that it played in mobilising women for the overthrow of the Abboud military regime in
1964, heralding a brief yet significant period of democracy in the country's history (1964-9), and one in which civil society and civic participation flourished. SWU's president at the time, Fatima Ahmed Ibrahim, became the first woman elected to parliament in 1965, a feat she achieved by running a campaign in a graduate constituency. However, she was the only one, and the women's movement realised that gains would not be made without changes to the political parties themselves, beginning soon after to engage party leadership and to build women's sectors within political parties themselves.

The 1968 general elections propelled a painful process of lesson-learning within the movement, which directly influenced the strategies that culminated in the 2008 quota. The elections saw the elimination of graduate constituencies, which was the only electoral pathway for women to parliament. With the graduate constituencies gone, political parties did not put forward women candidates in geographic constituencies, focusing their efforts in mobilising women to vote for male candidates instead. In that, they were successful: in some constituencies women outnumbered men in registration, and women voted in a similar proportion to men (72 per cent vs. 74 per cent) (Abdel-Al 1997). Thus, Sudanese women gained as voters but retreated as candidates, an experience that would influence the thinking of political parties who began viewing women as a critical voting block but not one which required representation in the nomination lists. The resistance of parties to nominate women unless special measures were put in place that did not cut into 'standard' party seats, was the first lesson of the Sudanese women's movement on the road to the quota.

The second lesson came with the seizure of power by Jafar Nimeri soon after the 1968 elections, which ushered in a decade and a half of military dictatorship. Nimeri was a believer in social reengineering. Totalitarian or not, women would be better represented in his parliament than under any previous government. He reserved 40 per cent of the seats in the National People's Assembly for women, professionals (which could of course include women), the armed forces, the business community and other groups that the regime saw as critical in combating the stranglehold of the traditional sectarian parties on rural psyches. Political representation was also 


\begin{tabular}{|c|c|c|c|c|}
\hline Year & Number of seats & Number of seats (men) & Number of seats (women) & Percentage of women (\%) \\
\hline 1965 & 171 & 170 & 1 & 6 \\
\hline 1968 & 261 & 261 & 0 & - \\
\hline 1972 & 265 & 252 & 13 & 5.1 \\
\hline 1974 & 261 & 250 & 11 & 4.4 \\
\hline 1978 & 318 & 300 & 17 & 5.6 \\
\hline 1980 & 386 & 368 & 18 & 4.9 \\
\hline 1982 & 165 & 154 & 11 & 7 \\
\hline 1992-96 & 200 & 180 & 20 & 10 \\
\hline 1986 & 303 & 301 & 2 & 0.7 \\
\hline 1994 & 284 & 258 & 26 & 9.2 \\
\hline 1996 & 421 & 400 & 21 & 5 \\
\hline 2001 & 385 & 350 & 35 & 7 \\
\hline $2005^{*}$ & 450 & 369 & 81 & 18 \\
\hline
\end{tabular}

*Transitional parliament, appointed following signature of the CPA.

Source Teks (2008).

accompanied with political repression on the streets as women's organisations became subject to banning, encroachment and attempted cooption. The SWU would enter a difficult phase in its history from which it would never fully recover, with some members abandoning it and aligning themselves with the ruling regime, renaming themselves 'the socialist union', while the remainder retained the old name and maintained their opposition to the regime (Abdel-Al 1997).

The return to multi-party rule in 1985 and multiparty elections in 1986 would remind the women's movement of the lessons of the 1960s. Graduate constituencies were reinstated, and as before, they represented the main opening to women. ${ }^{2}$ In all, only one woman ran in a geographical constituency and only five in graduate constituencies, with two of the latter winning seats. As voters however, women turned out en masse, and in unprecedented numbers.

Nimat Kuku (2009) writes of the lessons of this period:

What has been noticeable is that women's push in political work did not result in increased numbers of women in parliament. The problem manifested itself in the inadequate number of nominees on the one hand and on the other their absence from 'safe districts' and the top of the graduate constituency lists. The other lesson was that women who went into parliament in the 65 and 86 elections went through lists and not geographic constituencies, and for certain parties and not others. In fact the largest representation for women was achieved through reserved seats guaranteed by the constitution of 1973 and subsequent election laws during the May [Nimeri] regime, thus through quotas.

Multi-party rule, as had been the case throughout Sudan's modern history, was short-lived. The coup of 1989 brought the National Islamic Front (the 'Salvation' regime) to power and ushered in the most fractious political phase yet. Like Nimeri, the Salvationists attempted social re-engineering, which they called the 'civilization project', and women were one of the project's main targets for civilizing. The banning of political parties, trade unions, professional associations, and student groups accompanied restrictions on women's lives under a conservative interpretation of sharia law. The Islamist political tradition in Sudan, influenced by the charismatic Sheikh Hassan AlTurabi, had always seen a political role for women. 
The regime was thus less interested in excluding women per se from power, rather in excluding women associated with the opposition. It began eliminating existing women's organisations and set up its own structures, most notably, the Sudanese Women's General Union (SWGU), a statesupported organisation with a leadership handpicked by the ruling party. True to the Sudanese trend of higher parliamentary representation of women under dictatorships, the regime appointed a sizeable number of women to its various parliaments (see Table 1). ${ }^{3}$ The highest proportion (18 per cent) would only come after the signature of the CPA however, through appointment (mostly by the NCP but also the SPLM) to the transitional National Assembly in 2005.

The early years of the Salvation regime also saw in an intensification of the civil war in the South. The conflict further spread to the eastern region of the country when northern opposition groups, including the DUP and Umma Party, aligned themselves with the SPLM, and launched attacks on government targets from neighbouring Eritrea. Political openings only came after a major split within the ruling party in the late 1990s, from which the President, Omar Hassan Al-Bashir emerged victorious, and which helped bring a new openness to engagement with other political forces in the country. At first, the dialogue was tentatively extended to the main northern parties, many of which were allowed to register again. Soon, the NCP was speaking to its biggest foe, the SPLM, laying the ground for the negotiations that would lead to a historical peace agreement in 2005.

\section{The Comprehensive Peace Agreement: negotiating peace}

The quota had been an issue that surfaced in the 1990s fleetingly propelled by Sudanese women's participation in the Beijing summit who lobbied the national Democratic Alliance and other political forums. But political reform seemed distant then. The first sign that a peace agreement was imminent was the Machakos Protocol, which was signed in 2002 between the NCP and the SPLM, providing a framework for the CPA. Northern and southern women's groups began to mobilise, seeing that political reform was near but unclear what shape it would take, and with limited access to the negotiations. Most notably, the Sudanese Women's Empowerment for Peace (SuWEP) group - an alliance of northern and southern women activists - were early to act, presenting their vision for women's rights in a peace agreement, including a quota.

Women in southern Sudan, conscious that any agreement signed by the SPLM would contain a large degree of autonomy for southern Sudan, were agitating for a similar provision. But as with their counterparts in the North, they were undermined by a patriarchal political culture that resisted the inclusion of their voices. As Anne Itto (2006), a political activist from southern Sudan, has written:

The SPLM/A leadership nominated a handful of women leaders as members of the delegation to Machakos and subsequent rounds of negotiations. However, this did not necessarily enable their strong participation: the women were often co-opted to these delegations at short notice with very little opportunity to consult with each other and develop a women's peace agenda; they were expected to contribute to the overall party position, which was gender-blind to begin with; and they were always a minority, illprepared for debates with seasoned politicians who ridiculed or intimidated anyone who dared to spend much time on gender issues.

One of the first issues the women in the South put forward was a 25 per cent quota. This was summarily dismissed by a senior member of the SPLM, and then an all-male SPLM committee reduced the figure to 5 per cent, with the SPLM chairman raising it to 10 per cent. 'Later on', writes Itto, 'we learned that it had been dropped altogether when government negotiators refused a quota for women in power sharing on the grounds that they had not been fighting women' (2006). The negotiations were thus a painful experience for women, whom the war had affected disproportionately, and many, such as Itto herself, had been long engaged in the struggle.

In January 2005, the Comprehensive Peace Agreement (CPA), otherwise known as the Naivasha protocols, was finally signed, without a quota provision. Although representing the most important political opening in Sudan in at least a decade and a half, the CPA had several flaws that would come back to haunt it. The first and most important was that it was a bilateral arrangement between two political groups to the 
exclusion of others. It was assumed that the NCP represented the North and the SPLM the South, when in fact there was sizeable political opposition in the country, particularly to the former. The agreement also assumed that resolving wealth and power inequities between the North and South would bring stability to the rest of the country. The outbreak of another violent conflict in the Darfur region of western Sudan (in the 'North') as the agreement was being negotiated belied the assumption that the North formed an ethnically, religiously and linguistically homogenous group, and that systematic underdevelopment was a problem that only affected the South. Itto points out that the CPA was also an overwhelmingly male driven affair with power sharing interpreted as dividing government posts among parties to the conflict, namely the SPLM and the NCP. Nevertheless, the recognition of rights as the basis of citizenship regardless of religion, ethnicity, and gender and the key milestones the CPA set on the road to peace - namely constitutional reform and multiparty elections - gave activists an opening. 'We focused everything on the coming transitional constitution, ${ }^{4}$ says Tayseer El-Nourani, a political party activist and women's rights advocate.

\section{Constitutional and legal reform - a closed process}

One of the first institutions created by the CPA was the National Constitutional Commission, tasked with drafting an Interim National Constitution (INC). Southern Sudan would have its own interim constitution as well, in addition to new state constitutions for the newly redrawn 25 states (15 in the North and ten in the South.) The period following the CPA saw a great deal of effort by women's groups, most notably the Political Party Women's Forum which had formed in Khartoum in 2004, to mobilise around the quota. Keen to avoid a repeat of the exclusion women faced during the peace negotiations, this group amongst others attempted to act quickly so as to influence the constitutional and legal reform processes set to take place.

The issues at first centred on what percentage to go for, with most in the North advocating for the Beijing Platform recommendation of 30 per cent. However, 25 per cent was the percentage acceptable to several prominent parties, including the NCP. SPLM women were also committed to that figure, which they had put forward on the negotiating table in Naivasha. Given the fact that power lay in the hands of the two parties to Naivasha, the 25 per cent soon gained traction. As the battle for the law heated up, and more pressure developed on women's groups to decide not only how much to go for but what form the quota should take, fissures began to resurface within the movement. Nourani notes:

The Sudanese women's movement [in northern Sudan] is split into two: opposition and government ... when it comes down to it, the perspective of women affiliated with the government is different from that of women in the opposition - even though there could be issues in common. We have a problem because our mentality in the opposition is that of our parties and because their mentality is that of their party which is ruling. ${ }^{5}$

With female political activists from outside the NCP having little access to the constitutional panel tasked with drafting the document, they attempted to influence it to the full extent possible from outside through various means: by engaging the media, through protests and the submission of a memo to the constitutional review panel outlining their vision. They failed however to push this vision through, as the constitution, like the CPA, was adopted without any mention of the quota. The constitution did however depart from previous ones in one important way - not only did it have a relatively strong and supportive stance on women's rights, but it also contained, critically, a provision for affirmative action in favour of women. In what way that affirmative action would be applied was left open. Overall, the activists who had lobbied for the quota felt that they had lost another battle. ${ }^{6}$ Feelings of failure in the North were compounded by the success in the South in incorporating a 25 per cent provision in the South Sudan Interim Constitution, not only in all of the Government of South Sudan's legislative bodies but in its executive structures as well. NCP activists argued, however, that the omission of the quota from the Interim National Constitution was not a failure, rather a deliberate strategy. As Afaf Ahmad AbdelRahman Mohamed, a senior member of the NCP, former parliamentarian, and member of the constitutional panel explained, the idea was to arrive at a wording that would guarantee the most flexibility and possibilities for change. ${ }^{?}$ 
With the constitutional battle proving indecisive but leaving the door open for the quota, women activists soon realised that the electoral laws would be the final battleground. The fissures within the movement widened during the three years between the enactment of the constitution and the electoral law of 2008, as the women faced pressure to define what form the quota should take. Samia Al-Hashimi (2008), a lawyer and activist reflects on this period:

The strong conflict that occurred between women groups on the way in which women should be included in the laws was an important moment in the history of Sudanese women. The government's vision and that of women affiliated to it was of a separate women's list, while the vision of the rest of women was to include women on the same lists as their parties.

Women activists, however, formed a voluntary panel of seven gender experts and activists from diverse political persuasions, and, supported by the Frederich Ebert Foundation in Sudan, set about to come up with a proposal with which they could mobilise and influence government. Their proposal was the following:

- A 30 per cent quota for women in composition of the National Elections Commission, which would be formed to oversee the elections, as well as its state high elections structures

- A Quota in party lists at federal and state level of no less than 30 per cent

- A clear mechanism to guarantee women's inclusion in the upper half of party lists, so as to avoid their relegation to the bottom, and ramifications against the parties were this not to be adhered to. (Nourani 2009)

When the law was finally issued in 2008, it included the quota, but not the form most activists desired. The law stipulated the following:

Out of 450 seats in the National Assembly: - 270 (60 per cent) would be filled by simple majority to represent the geographic districts in every state.

- 112 (25 per cent) would be filled through separate and closed women's lists at the level of states, where each voter votes for one women's list only (and for the whole list as opposed to specific individuals on it). For lists to qualify for a seat they must receive no less than 4 per cent of the vote. The seats designated to the women's lists shall then be allocated on the basis of the number of votes obtained by each list related to the strength of the seat after excluding non-qualifying lists (those that did not receive at least 4 per cent of votes). Finally, assignment of the seats goes to candidates on those qualifying lists in the order that their names appear, from top to bottom.

- 68 (15 per cent) would be filled from party lists based on proportional representation. (National Elections Act 2008, Sudan, articles 29-33)

The law also stipulated a 25 per cent quota through women's lists at the state legislative councils and the same in the South Sudan Legislative Assembly (SSLA) (Nourani 2009).

The victory was bitter sweet. On the one hand, a historic achievement had been made by Sudanese women: for the first time, 25 per cent of seats at the national and state levels would be filled by women. On the other hand, the form the quota took was seen by many activists as isolating women within their parties, making separate lists for them that would give parties little incentive to nominate them in the 'core' geographic constituencies or even party lists. The opposition women termed the separate list 'Hoesh al-Nisa' (the women's yard), referring to the traditional division of space in the Sudanese home where women have their own area in the house that they are meant to stick to. They also feared that a separate women's list negotiated mainly through parties would put them at the mercy of powerful male brokers within the party, and that a situation where lists competed against one another (i.e. women competed against other women rather than against candidates from both sexes) would not be conducive to forming inter-party women's alliances and bringing into legislative bodies a plurality of women's voices and perspectives, since lists would be party-based and since the dominant list (i.e. dominant party in terms of votes) would then dominate the allocated seats.

\section{The 2010 elections - early thoughts}

The first Sudanese general elections took place in April 2010, amidst much political turmoil, accusations of fraud directed at the NCP, and a political crisis that resulted in the boycotting of the elections (at the very last minute) of most 


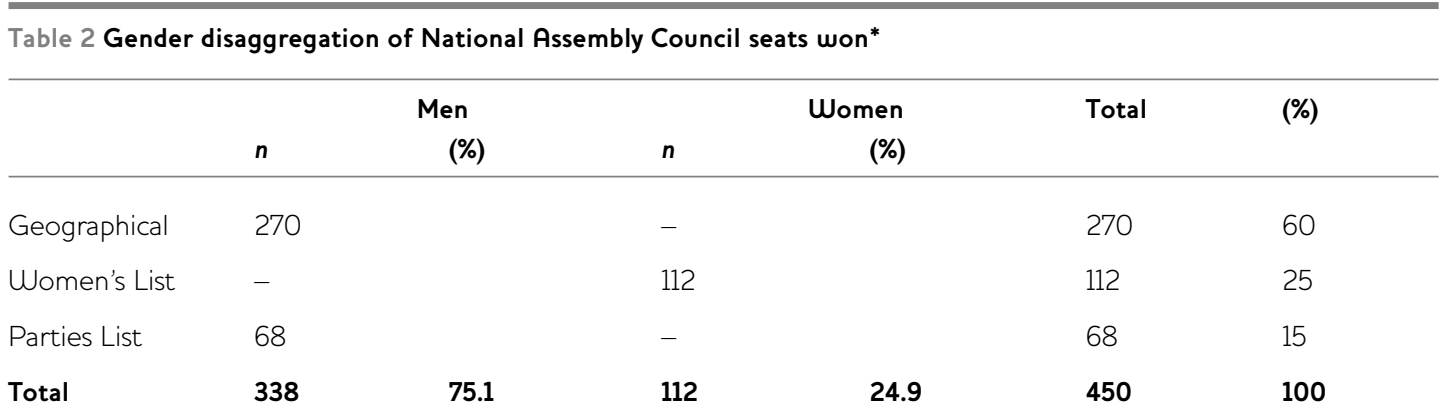

*Data from the National Elections Commission gender advisor, unpublished as yet.

Source Al-Mubarak (2010).

major opposition parties. Many of the fears of women activists regarding the impact of the form the quota took proved true. Preliminary results show the NCP winning all 112 women's seats in parliament, and the majority of the state legislative council seats (Al-Mubarak 2010). ${ }^{8}$ Not a single woman in the North won seats through a geographic constituency or a party list (see Table 2), reflecting to a large extent the weak representation in the nominations' lists to begin with.

The boycott by opposition parties makes it difficult to evaluate whether the outcome would have been the same had they participated in the elections. In addition, the exclusion of large segments of Darfur from the elections due to the violence in parts of the region have meant that millions of women of most need for advocates in parliament were left without the opportunity to make their voices heard. Because of the above issues and the fact that the elections are not yet over (Gezira State and South Kordofan, two northern states, have had to delay their state elections), it is difficult to make definitive conclusions about the elections. But what we do know is that the experience of women candidates has raised a range of issues beyond the quota that have had a critical impact on their candidacies, and that have received much less attention. These include an acute lack of funds (in the case of women outside the ruling parties); little know-how on how to form platforms and run campaigns; few training opportunities; little access to the media; difficulty in obtaining critical information from electoral bodies particularly in rural constituencies; intimidation and harassment in some cases and continued marginalisation within party structures and processes in many others.
Most of the nominees had never had the opportunity to vote in multi-party elections to begin with, let alone run in an extremely complex set-up whereby voters in the North cast eight ballots and those in the south 12, under conditions of widespread illiteracy. The voters they were targeting for their part had been absent from the polls for a long time, and many, especially women, knew little about the process of elections, and had little access to information about most of the candidates; an issue of special relevance to women candidates in terms of building a voting constituency, as they tend to have less resources to conduct door-to-door campaigns and less access to the media. The form that the quota has taken encourages women to compete against one another, both within their parties as well as against other lists.

Although the scenario presented above can be read as negative, it is important to note that the quota did have its achievements as well, which I would argue go much further in their implications for the women's movement in Sudan than the numbers entering legislative bodies in 2010. The most enduring legacy of the 2008 quota is likely to be the extent to which it mobilised women to enter politics. Research by Balghis Badri, a professor at Ahfad University for Women in Khartoum, shows that the number of women candidates in the 15 states of northern Sudan reached 2,872 (National and State) (Badri 2010). A total of 112 will be entering this session of the National Assembly, compared with only two in 1986. In South Sudan overall, the female representation has increased significantly (from 19 per cent to 31.76 per cent for SSLA, and from 22 per cent to 28.33 per cent for State Assemblies (UNIFEM 2010). 


\section{The quota: done and dusted?}

The history of northern Sudanese women's access to parliament reveals two interesting trends. The first is that single party rule, under military dictatorship in Sudan's case, brought women in much larger numbers to parliament, mostly by guaranteeing them a set number of seats. During the brief periods of multi-party rule however, where access to parliament came through the ballot, women's only pathway to legislative bodies came through specially designated 'graduate constituencies', open to women and other groups, mostly urban workers and professionals, who without special provisions would have had difficulty being elected in a political scene dominated by sectarian parties with large sway in the rural areas.

Parties were, and remain, reluctant to nominate women in standard geographic constituencies, from which the vast majority of candidates are drawn. The mobilisation for a legislative quota for women both before and after the historic peace agreement of 2010 sought to learn from the past and break with it by guaranteeing a sizeable place at the table for Sudanese women within multi-party democracy.

Through much struggle, advocacy, research and negotiation, they succeeded in pushing through a quota in 2008 that is unprecedented in Sudan's history. The legacy of the quota is likely to be not so much the increase in numbers, but the way in which it mobilised Sudanese women and propelled them into the political sphere. Their failure, however, to unite in vision on what form this quota should take, and the lack of influence of women outside the ruling party on those inside it, has left the women's movement with a quota system that is arguably non-conducive to en-gendering political party structures and processes, and that can encourage women to divide rather than unite on a sorely needed common agenda.

Beyond calls to reform the quota in light of the experience of the 2010 elections, it is critical to remember that the quota is designed as a temporary measure. En-gendering political party structures and electoral bodies, raising women's and men's awareness about the contributions and capacities of women for office, including the rural areas where outreach has been key, are imperative. While the quota battle in northern
Sudan was mainly fought in Khartoum (though its impact was much wider), it is important to reach out to women outside the large urban centres and work with them on how best to increase women's political power in their areas. Opportunity exists to tackle the above issue in the coming few years at the level of local government - which is likely to come under the spotlight, regardless of whether unity or secession is the choice of the people of southern Sudan. The women's movement, if it is to avoid the mistakes of the transitional period, needs to mobilise early and negotiate a common vision on how best to increase women's meaningful participation in local government, whether at the local councils of the mahaliyat (districts, or Payams in the South) or at the level of the grassroots popular committees that currently play no effective role in the delivery of services and mobilisation of population for development at the neighbourhood level.

Engaging other non-formal governance structures in Sudan, most notably traditional and religious authority is also key, as they continue to play an important role in the allocation of power and resources at the local level.

Moreover, the international community, which bank-rolled the 2010 elections, was for the most part late in funding training of women candidates, civic and voter education efforts, and capacity-building of domestic observers - all elements of the electoral environment that if strengthened can help the realisation of more positive outcomes for women.

The women's movement in Sudan, although not always hand-in-hand, managed to reach a common goal of the quota, although the form it took was divisive. NCP women may not be the most progressive, but the gender dynamics of the Sudan mean that they are likely to face barriers within parliament, regardless of political affiliation. Little effort has been made to engage them in a constructive way, and they have made little effort to engage others. This has been a weakness of the movement since this regime took power, and it has hindered its effectiveness.

Finally, the continued restrictions on political organisation and the continued hurdles on democratic practice, despite the CPA, remain important limits on women's participation in politics, in particular at the level of political parties. The women's movement cannot be 
divorced from the larger reality of the country, which is that Sudan is a country between war and peace, democracy and dictatorship, unity and secession. What role the movement will play in

\section{Notes}

* I would like to extend sincere thanks to Tayseer El-Nourani, Nimat Kuku, Sara NugdAllah and Afaf Ahmad Abdel-Rahman Mohamed, who spoke to me in their personal capacities, and whose generous insights greatly contributed to this article. Special thanks to Lamya Ibrahim Badri for her friendship and her selfless support throughout. Any shortcomings in the article remain mine alone.

1 Legislative councils are state level councils tasked with legislating at the state level and governed by separate state constitutions.

2 Interview with Sara Nugd-Allah: member of Umma Party leadership, 22 January 2010.

\section{References}

Abdel-Al, Mahasin (1997) 'Sudanese Women and Political Work: The Women's Movement as the Legacy of the Nationalist Movement', unpublished, Khartoum

Al-Hashimi, Samia (2008) 'Women's Rights in Political Party Constitutions and Directives', in The Women and Elections Workshop, organised by Frederich Ebert Foundation and Sudanese Studies Centre, 19 and 20 August [in Arabic]

Al-Mubarak, Suad (2010) 'Legislative Election Results - 2010 Gender Data, Northern Sudan States', unpublished

Badri, Balghis (2010) 'The Impact of the Application of the Women Quota System in the Electoral Law of Sudan 2008', paper presented at the Conference on Sudanese Women Voice: Support and Elect Her, UNIFEM and the Political Parties Affairs Council (Sudan), 23-25 March, Khartoum

El-Battahani, Atta (2002) 'Multi-Party Elections and the Predicament of Northern Hegemony' in Michael Cowen and Liisa Laakso (eds), Multi-party Elections in Africa, Palgrave Macmillan affecting this balance is yet unclear, much of it will depend on whether it can negotiate its differences and build on the momentum of the quota - and how quickly.

3 The author is aware that there are discrepancies in the figures presented in Table 1 , however, in view of the paucity of data in the Sudanese context, this is one of the few sources available on trends and patterns of political representation.

4 Interview, 4 October 2009, Khartoum.

5 Interview, 4 October 2009, Khartoum.

6 Interviews with Tayseer Al-Nourani, Nimat Kuku, and Sara Nugd-Allah (4 October 2009; 19 October 2009 and 22 January 2010).

7 Interview, 21 June 2010.

8 Gezira and South Kordofan states are yet to hold their state elections, which had to be postponed.

El-Nourani, Tayseer (2009) 'The History of the Quota', unpublished, Khartoum

Itto, Anne (2006) 'Guests at the Table? The Role of Women in Peace Processes', in Mark Simmons and Peter Dixon (issue eds), Peace by Piece: Addressing Sudan's Conflicts, Issue \# 18 of Accord: An International Review of Peace Initiatives, London: Conciliation Resources

Kuku, Nimat (2009) 'Elections and Gender' in Mafaheem (Concepts): A Theoretical Framework for Knowledge, Khartoum: The Gender Centre for Training and Research [in Arabic]

Republic of Sudan National Elections Act for 2008, Ministry of Justice

Teks, Mariam Abdul al-Rahman (2008) 'The Sudanese Woman in Parliament', in the Women and Elections Workshop, Sudanese Studies Center and Frederich Ebert Foundation, 19 and 20 August [in Arabic]

UNIFEM (2010) 'Gender Disaggregated Results of the 2010 General Elections - Southern Sudan only', presentation by UNIFEM to the UN Country Team, Southern Sudan, 17 May 